2. To: (Receiving Organization)

Characterization \& Interim Stabilization Engineering

5. Proj./Prog./Dept./Div.:

\section{Characterization Project} Operation

8. Originator Remarks:

For review and approval

11. Receiver Remarks: 11A. Design Basel ine Document? [] Yes [X] No
3. From: (Originating Organization)

B. L. Philipp

6. Design Authority/ Design Agent/Cog. Engr.: G. $\mathrm{P}$. Janicek/

C. A. Esvelt
4. Related EDT No.:

N/A

7. Purchase Order No.

$N / A$ 


\section{LIGHT DUTY UTILITY ARM COMPUTER SOFTWARE CONFIGURATION MANAGEMENT PLAN}

B. L. Philipp

B. L. Aftanas

COGEMA Engineering Corp., Richland, WA 99352

U.S. Department of Energy Contract DE-AC06-96RL13200

EDT/ECN: 618864

Org Code: $08 \mathrm{E} 00$

UC: 2070

B\&R Code: EW3120074

Charge Code: $025 K 2$

Total Pages: 31

Key Words: arm, software, light duty utility arm

Abstract: This plan describes the configuration management for the Light Duty Utility Arm robotic manipulation arm control software. It identifies the requirement, associated documents, and the software control methodology.

UNIX is a trademark 1 icensed exclusively through $\mathrm{X} / 0$ pen Company $L$ td.

TRADEMARK DISCLAIMER. Reference herein to any specific comercial praduct, process, or service by trade name, trademark, manufacturer, or otherwise, does not necessarily constitute or imply its endorsement, recommendation, or favoring by the United States Government or any agency thereof or its contractors or subcontractors.

Printed in the United States of America. To obtain copies of this document, contact: Document Control Services, P.O. Box 950, Mailstop H6-08, Richland WA 99352, Phone (509) 372-2420; Fax (509) $376-4989$.
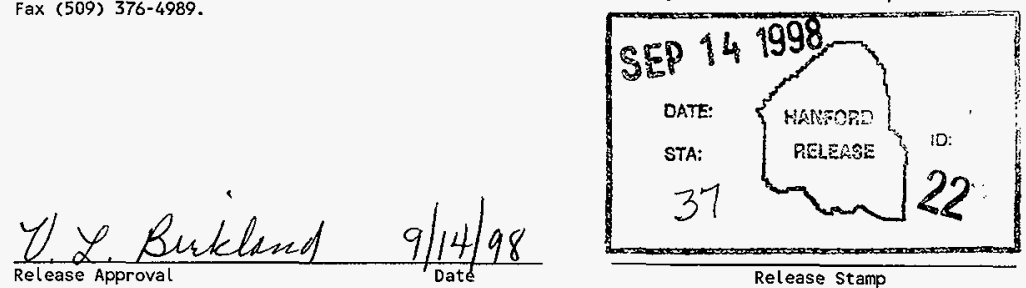

\section{Approved for Public Release}




\title{
LIGHT DUTY UTILITY ARM COMPUTER SOFTWARE CONFIGURATION MANAGEMENT PLAN
}

\author{
B. L. Philipp
}

B. L. Aftanas

August 1998

COGEMA Engineering Corporation

Richland, Washington 


\title{
LIGHT DUTY UTILITY ARM COMPUTER SOFTWARE CONFIGURATION MANAGEMENT PLAN
}

\author{
B. L. Philipp \\ B. L. Aftanas
}

August 1998 


\section{TABLE OF CONTENTS}

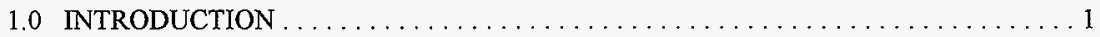

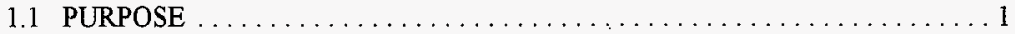

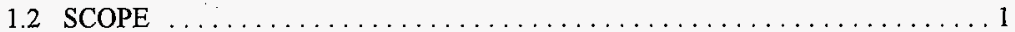

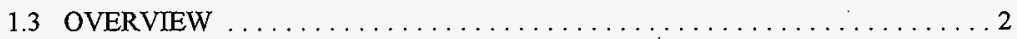

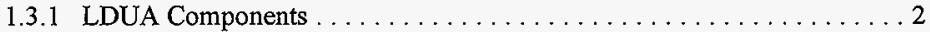

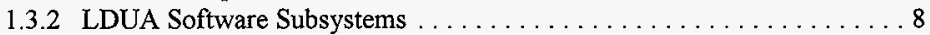

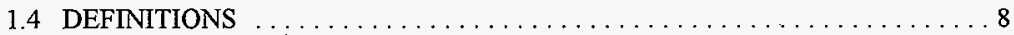

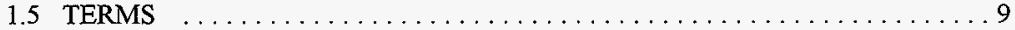

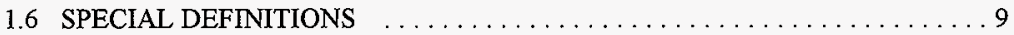

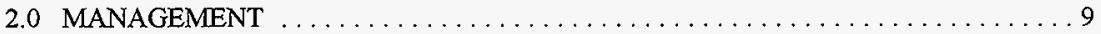

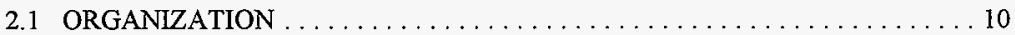

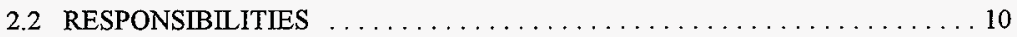

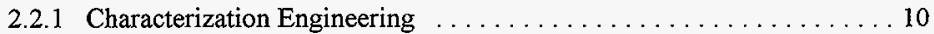

2.2.2 Characterization Project Operations . . . . . . . . . . . . . 11

2.2 .3 Nuclear Safety . . . . . . . . . . . . . . . . . . . . 12

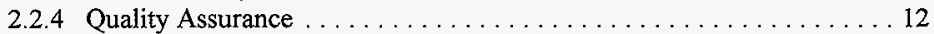

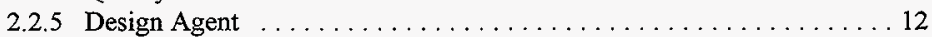

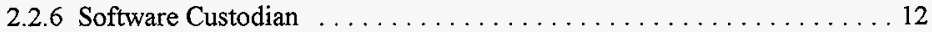

2.2.7 System Administrator . . . . . . . . . . . . . . . . . . 13

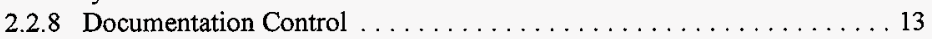

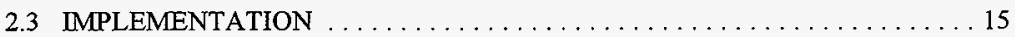

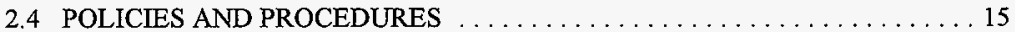

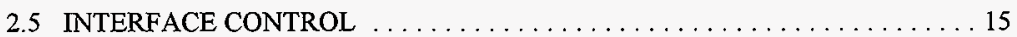

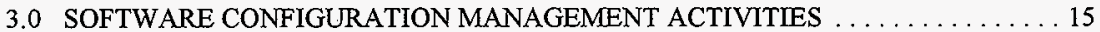

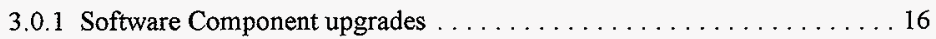

3.0 .2 UNIX System Upgrades . . . . . . . . . . . . . . . . . 16

3.0.3 Labeling of Software Media ..................... 17

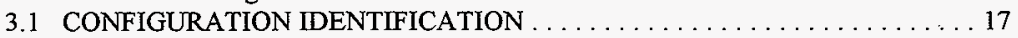

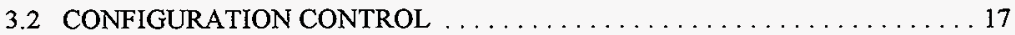

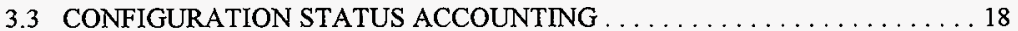

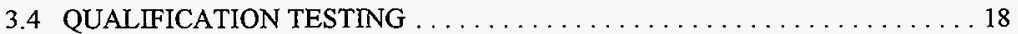

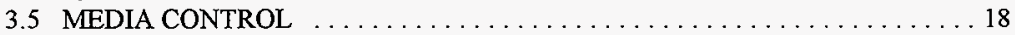

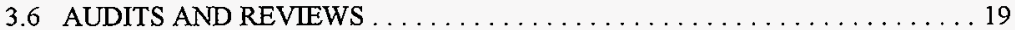

3.7 ACCESS CONTROL . . . . . . . . . . . . . . . . . . . . 19

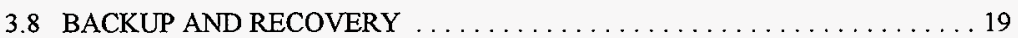

4.0 TOOLS, TECHNIQUES, AND METHODOLOGIES . . . . . . . . . . . . . . . 19

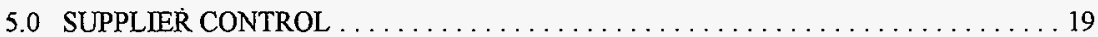




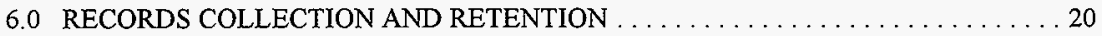

6.1 LDUA SOFTWARE LIFE CYCLE DOCUMENTS $\ldots \ldots \ldots \ldots \ldots \ldots \ldots . \ldots 20$

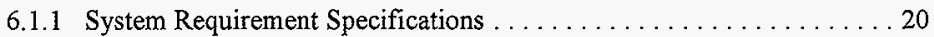

6.1 .2 System Design Description . . . . . . . . . . . . . . . . . 21

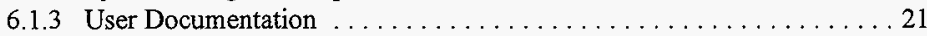

6.1 .4 Source Software ............................. 21

6.1 .5 Verification and Validation $\ldots \ldots \ldots \ldots \ldots \ldots \ldots \ldots \ldots \ldots \ldots \ldots \ldots \ldots, 22$

7.0 SAFETY, RELIABILITY, AND QUALITY ASSURANCE . . . . . . . . . . . . . 23

7.1 SAFETY CLASSIFICATION AND SIGNATURE DESIGNATION $\ldots \ldots \ldots 23$

7.2 QUALITY ASSURANCE AND QUALITY CONTROL $\ldots \ldots \ldots \ldots \ldots \ldots 23$

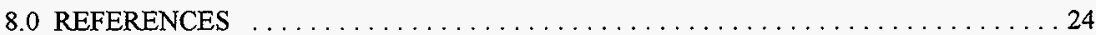

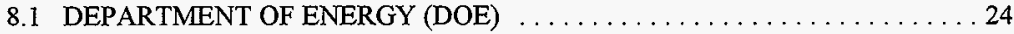

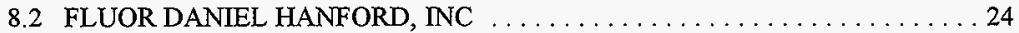

\section{LIST OF TABLES}

2.1. Organizational Responsibilities Matrix

\section{LIST OF FIGURES}

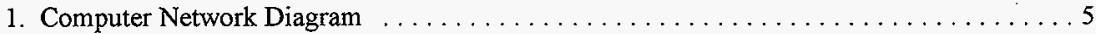

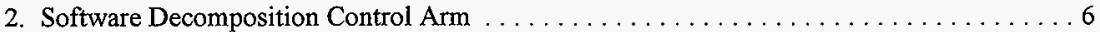

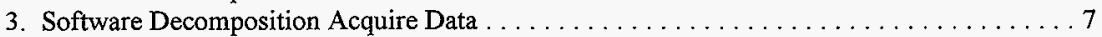


HNF-2924, Rev.0

\section{LIGHT DUTY UTILITY ARM COMPUTER \\ SOFTWARE CONFIGURATION \\ MANAGEMENT PLAN}

\subsection{INTRODUCTION}

The Light Duty Utility Arm (LDUA) System is a multi-axis robotic manipulator arm and deployment vehicle, used to perform surveillance and characterization operations in support of remediation of defense nuclear wastes currently stored in the Hanford Underground Storage Tanks (USTs) through the available $30.5 \mathrm{~cm}$ (12 in.) risers. This plan describes the configuration management of the LDUA software.

\subsection{PURPOSE}

This document provides the procedures and guidelines necessary for computer software configuration management activities during the operation and maintenance phases of the LDUA as required by HNF-PRO-555, Rev. 0, Software Practices - System Configuration Management Plan. The software configuration management plan integrates technical and administrative controls to establish and maintain technical consistency among requirements, physical configuration, and documentation for the Light Duty Utility Arm during the Hanford application operations, maintenance and future end effector development phases of the LDUA life cycle. This software configuration management plan establishes the LDUA Application Software System Baseline, statuses changes to that baseline, and ensures that software meets design and operational requirements and is tested in accordance with their design basis.

\subsection{SCOPE}

This plan applies to those organizations responsible for the operation and maintenance of the Hanford tank farm Application software for the Light Duty Utility Arm system. This LDUA computer software configuration management plan applies to the operational phase (including maintenance and transition to deactivation) of the present LDUA computer control systems and software as well as any future software development for new end effectors. Specific scope objectives for the LDUA application software configuration management plan are:

1. Establish and maintain the requirements and associated documents to accurately reflect the ARM, World Model, and End Effector software in the LDUA Application software and control system.

2. Identify and maintain the documents within the scope of the software configuration management plan (see Section 6.1). 
3. Control and status changes to systems and software to ensure the continued quality of the requirements, physical configuration, and documentation.

4. Conduct assessments to ensure that the software configuration management plan is effective in establishing and maintaining the technical requirements.

\subsection{OVERVIEW}

The LDUA integrated control and data acquisition system is computer based, with several workstations and embedded CPUs that communicate (Computer Network Diagram [Figure 1]). Its architecture is designed as a supervisory level coordinating the operation of a collection of subsystems, each with complementary capabilities. Some subsystems operate as supervisors. Other subsystems are capable of responding to direction from and reporting information to the supervisory level.

The supervisory level is divided into supervisory control, supervisory data acquisition, video display and recording, and network control. The supervisory level is concerned with centralization of control and data acquisition functions and with coordinating operation between subsystems. Supervisory operations are all conducted from the Operations and Control Trailer (OCT).

Ancillary subsystems support the main deployment equipment, performing such functions as: maintaining confinement of the tank atmosphere; decontamination of mast, arm, and end effector; power distribution; and observation of in-tank operations. Subsystems include the mast/arm, the end effectors (some mounted on the end of the arm and some deployed by separate riser interface systems), and the Tank Riser Interface and Confinement (TRIC).

\subsubsection{LDUA Components}

The supervisory level software (Software Decomposition Control Arm [Figure 2] and Software Decomposition Acquire Data [Figure 3]) will be stored on 8-mm and 4-mm data cartridges (see Section 3.5), and can be decomposed into the following major components:

Supervisory Level

a. Supervisory Control System

i. LDUA Console

ii. SCS Console

(1) World Model Software

(2) SGCS software

(3) Commercial robotic simulation software

b. Supervisory Data Acquisition System

i. Supervisory Data Acquisition System (SDAS) Console

ii. VME Chassis 
iii. Commercial Data Acquisition Software

iv. Commercial real time operating software

v. LDUA Specific Software

(1) SDAS Server Software

(2) TopSDAS User Interface

(3) GuestSDAS User Interface

c. Video Display and Recording System

i. Data Acquisition Workstation

d. Control Network

These major components parts of the LDUA were supplied by a consortium of DOE sites and National Laboratories, some of them in partnership with commercial suppliers. For clarification, a brief description of each component and how they interface is given.

Supervisory Control System

- The LDUA Console was provided by SPAR and operates the LDUA, VPM, and MDS. It provides display and access to the detailed status and operating parameters of the LDUA Subsystem controller.

- The SCS Console operates in conjunction with the LDUA Console. It provides a 3-D animated version for visualizing and previewing the motion of the VPM and LDUA in the environment of the tank. This simulated motion can be used as a preview to check for collisions between the LDUA and the tank structures or waste surfaces. Three different software packages comprise the robot simulation software. IGRIP from Deneb Robotics is the commercial simulation software distributed with the LDUA system. The SGCS software that runs on the SCS Console was provided by SPAR. The World Model software is Hanford specific and is composed of files that customize the robotic simulation software.

Supervisory Data Acquisition System

- The SDAS Console provides the primary user interface for operating end effectors, collecting data, and for monitoring and controlling the TRIC environment subsystems. It provides a single point from which data can be acquired, processed, and stored. The SDAS Console runs LDUA specific software over a commercial data acquisition software package.

- The VME Chassis provides a platform for an industry standard embedded processor and data acquisition boards. The embedded processor runs LDUA specific software over a commercial real time operating system. 
- The commercial data acquisition software distributed with the system is LabVIEW from National Instruments.

- The commercial real-time operating software distributed with the system is VxWorks from Wind River Systems.

- The LDUA specific software was developed by one of the DOE contractors in the consortium. The Hanford specific SDAS Server Software calls the server runs in the VME embedded processor, provides a data acquisition database, and provides the client interface for the SDAS and Guest Consoles. The Hanford specific TopSDAS and GuestSDAD software customizes the behavior of the commercial data acquisition software.

The Video Display and Recording System (VDAS) provides video monitors and video recorders to display and record pictures from the video cameras in the LDUA System, including units on the LDUA, in end effectors, and in ancillary equipment. The Data Acquisition Workstation controls all aspects of video switching, display and recording including the signal routing and overlaying of titles and other information onto the videos.

The Control Network ( $\mathrm{CN}$ ) provides a common network for all LDUA subsystems to intercommunicate. The network backbone is a twenty-four port hub located in the OCT with 10Base Twisted pair Ethernet connections for each computer. The control network uses standard Hanford Local Area Network (HLAN) components whenever possible so that maintenance is done by the LMSI network maintenance force. 


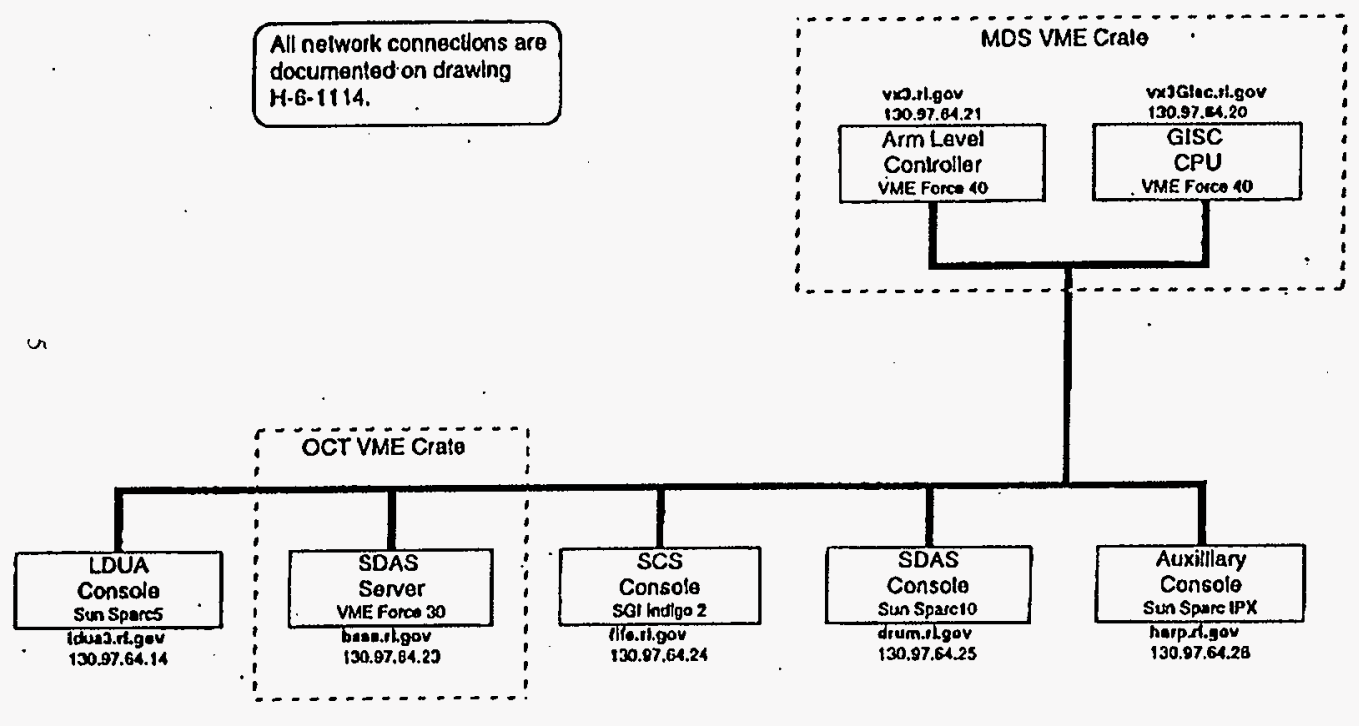




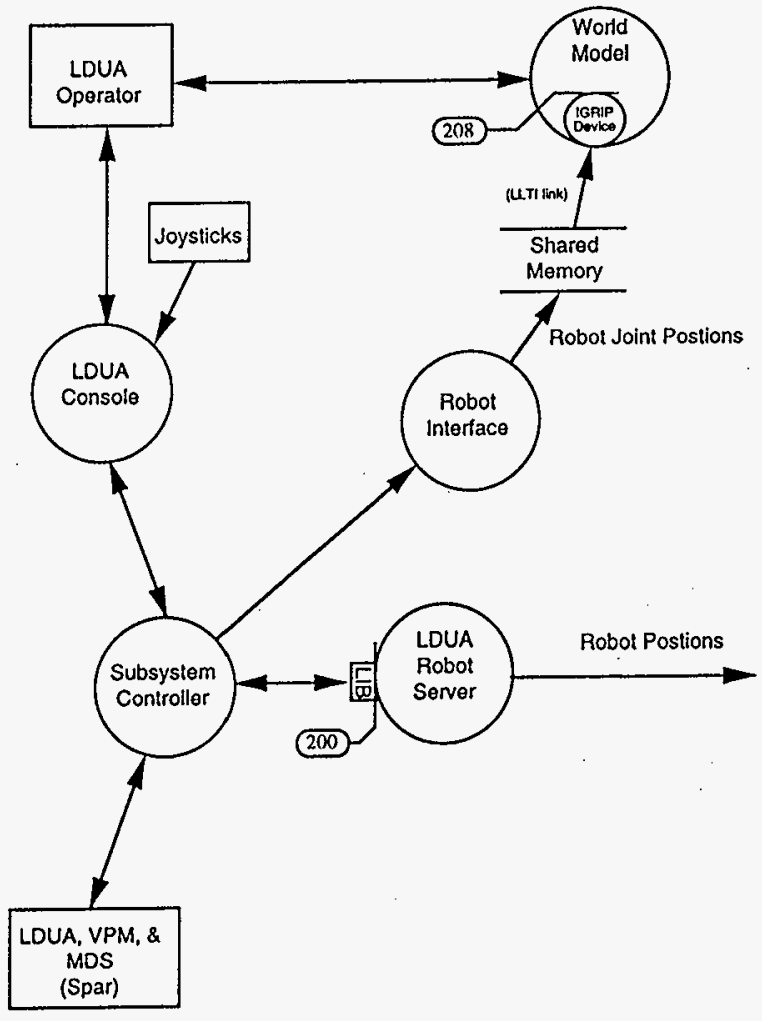


HNF-2924, Rev.0

Figure 3. Software Decomposition Acquire Data

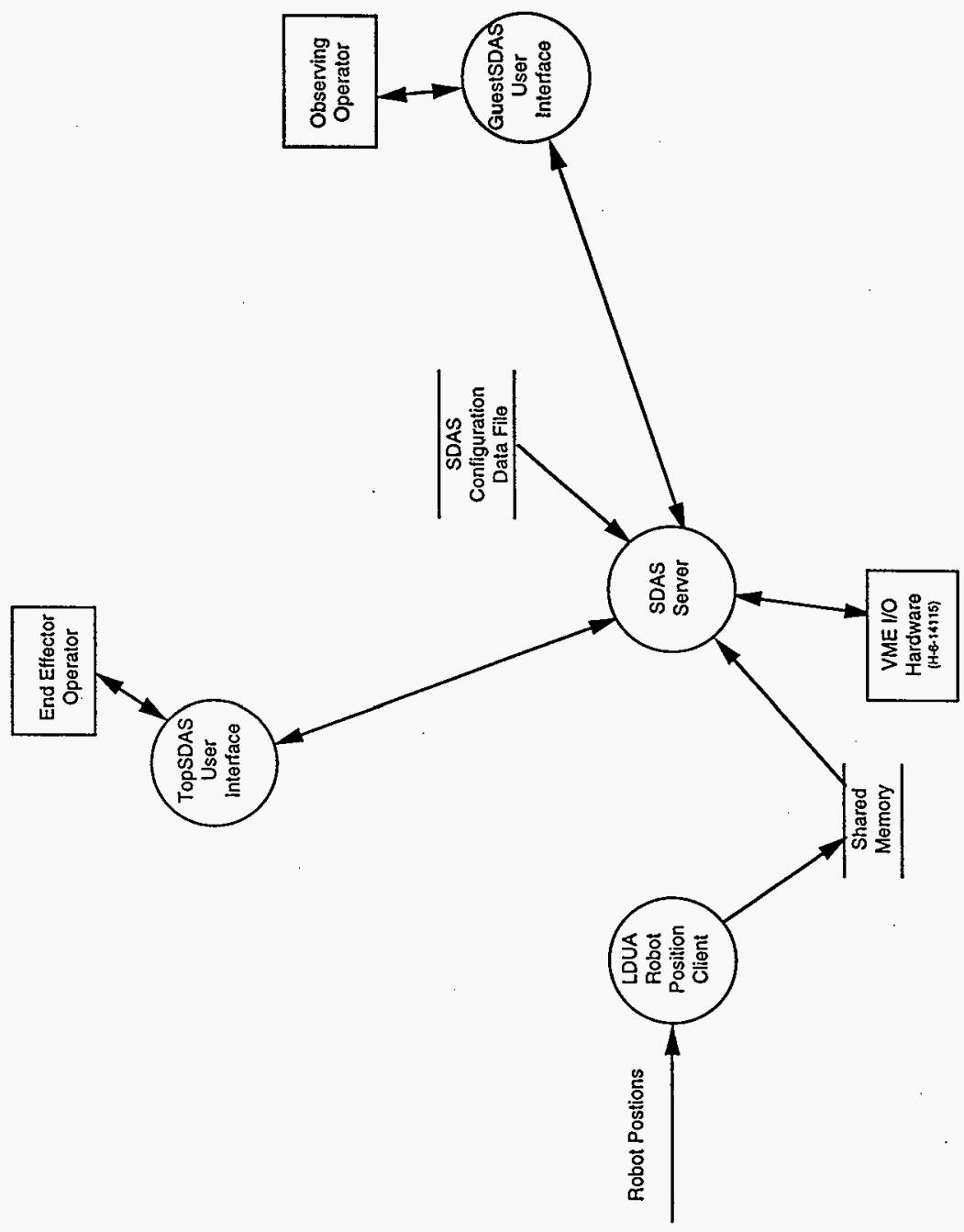




\subsubsection{LDUA Software Subsystems}

The actual LDUA software components can be divided into three major subsystems: the ARM software, the "World Model" software, and the End Effector software. The source code and documentation for the ARM software is proprietary commercial software written and owned by SPAR Aerospace Ltd. (SPAR). The source code and documentation for the "World Model" software and End Effector software were written by Pacific Northwest National Lab (PNNL) with significant contributions from Sandia National Laboratories (SNL). PNNL was responsible for delivery of an integrated final system, for taking ownership of the completed system until turnover to Lockheed Martin Hanford Corporation Operations, and for assuring that it is presently qualified for deployment in Hanford's Underground Storage Tanks (USTs).

\subsection{DEFINITIONS}

$\begin{array}{lll}\text { a. } & \text { ARM } & \text { - Arm/Deployment System (synonym for LDUA System) } \\ \text { b. } & \text { CN } & \text { - Control Network } \\ \text { c. } & \text { CSDD } & \text { - Computer Software Design Description } \\ \text { d. } & \text { CSRS } & \text { - Computer Software and Requirements Specification } \\ \text { e. } & \text { D\&D } & \text { - Decommissioning and Decontamination } \\ \text { f. } & \text { DOE } & \text { - United States Department of Energy } \\ \text { g. } & \text { DOE-RL } & \text { - DOE Richland Operations Office } \\ \text { h. } & \text { FDH } & \text { - Fluor Daniel Hanford Corporation } \\ \text { i. } & \text { HLAN } & \text { - Hanford Local Area Network } \\ \text { j. } & \text { IGRIP } & \text { - Commercial simulation software from Deneb Robotics } \\ \text { k. } & \text { LMHC } & \text { - Lockheed Martin Hanford Company } \\ \text { 1. } & \text { LMSI } & \text { - Lockheed Martin Service, Inc. } \\ \text { m. } & \text { LDUA } & \text { - Light Duty Utility Arm } \\ \text { n. } & \text { MDS } & \text { - Mobile Deployment System } \\ \text { o. } & \text { OCT } & \text { - Operations and Control Trailer } \\ \text { p. } & \text { PHMC } & \text { - Project Hanford Management Contract } \\ \text { q. } & \text { PNNL } & \text { - Pacific Northwest National Laboratories } \\ \text { r. } & \text { RTDP } & \text { - Robotics Technology Development Program } \\ \text { s. } & \text { SCADAS } & \text { - Supervisory Control and Data Acquisition System } \\ \text { t. } & \text { SCR/PR } & \text { - Software Change Request and Problem Report } \\ \text { u. } & \text { SCS } & \text { - Supervisory Control System } \\ \text { v. } & \text { SDAS } & \text { - Supervisory Data Acquisition System } \\ \text { w. } & \text { SGCS } & \text { - SPAR software package for SCS Console } \\ \text { x. } & \text { SNL } & \text { - Sandia National Laboratory } \\ \text { y. } & \text { TRIC } & \text { - Tank Riser Interface and Confinement } \\ \text { z. } & \text { UST } & \text { - Underground Storage Tanks } \\ \text { aa. } & \text { VDAS } & \text { - Video Display and Recording System } \\ \text { bb. VPM } & \text { - Vertical Positioning Mast } \\ \text { cc. } & \text { V\&V } & \text { - Verification and Validation }\end{array}$




\subsection{TERMS}

a. Application Software performs or supports the performance of the primary service or function of the LDUA system. Application software is the general term applied to the software covered by this software configuration management plan.

b. LDUA Application Software System Baseline (Phase-3) will be set upon turnover to LHMC tank farm operations. The original system baseline (Phase-1) was set upon completion of the LDUA Phase-1 Qualification Test at the end of the development process. Phase-2 baseline status was defined following deployment into Hanford Tank T-106 and completion of the LDUA Phase-2 Qualification Test.

c. Master Copy is the official copy of the LDUA Application software. It is controlled by the LDUA Software Custodian and resides in the Application Software file cabinet.

d. Program Elements refer to everything needed to justify, define, and describe the physical and operational configuration of a Structure, System or Component (SSC). For LDUA this includes all computer control systems and associated software.

e. Software Life Cycle is the period of time that starts when a software product is conceived and ends when the product is no longer available for use.

f. System Software directly manages the physical computer resources on behalf of application software, and which supports it. For LDUA, this includes the computer operating system and its utility programs, data base management system, and the language compiler.

\subsection{SPECIAL DEFINITIONS}

a. Application Specific Software was developed by one of the DOE contractors in the consortium.

b. Special Commercial Software is supplied by a commercial vendor, but it is either not an off-the-shelf product or is not supported by the vendor.

c. Standard Commercial Software is available off the shelf in the open market and is fully supported by the vendor.

\subsection{MANAGEMENT}

Organizational roles and responsibilities are established to ensure that functional organizations are aware of the responsibilities required for implementation of this plan. 


\subsection{ORGANIZATION}

This plan applies to the following:

Tank Farm Characterization Engineering and Tank Farm Characterization Project Operations, currently performed by Lockheed Martin Hanford Corporation (LMHC),

Nuclear Safety, and Quality Assurance, currently performed by Lockheed Martin Hanford Corporation (LMHC),

LDUA Design Agent, currently performed by Pacific Northwest National Laboratory (PNNL), Software Custodian, currently performed by COGEMA Engineering Corporation (COGEMA Engineering), and

System Administrator, currently performed by Lockheed Martin Services, Inc. (LMSI).

\subsection{RESPONSIBILITLES}

Fluor Daniel Hanford, Inc. (FDH) is the management and integration contractor of the Hanford Site for the Department of Energy, Richland Operations Office (DOE-RL). FDH is responsible for developing and implementing requirements and procedures that establish management responsibilities and process methodologies.

\subsubsection{Characterization Engineering}

LMHC Characterization Engineering is responsible for:

1. Establishing and managing the coordination and interfaces of the LDUA software configuration management program elements defined in Section 6.1 .

2. Initiating the Application software changes.

3. Assisting in the identification, definition, and control of programmatic and technical interfaces.

4. Ensuring that software configuration management controls are used in the conduct of operations.

5. Identifying, establishing, reviewing, and approving minimum testing criteria.

6. Assisting in the review/acceptance of vender information.

\subsubsection{Characterization Engineering - Cognizant Engineer}


The Cognizant Engineer is the assigned owner of the LDUA's physical and operational system configuration and is responsible for:

1. Implementing and managing the software configuration management plan (shared responsibility with design authority).

2. Ensuring that complete and accurate technical documentation is developed and maintained.

3. Providing engineering direction and oversight to ensure that designs and modifications are consistent with the technical baselines.

\subsubsection{Characterization Engineering - Cognizant Manager}

The Cognizant Manager is responsible for :

1. Assuring that reviews and approvals appropriate to impact level are obtained for software and other configuration items.

\subsubsection{Characterization Engineering - Design Authority}

The Design Authority is the assigned owner of LDUA requirements, design baseline, and system configuration and is responsible for:

1. Controlling the evolving technical baseline.

2. Implementing and managing the software configuration management plan (shared responsibility with Cognizant Engineer).

3. Ensuring that complete and accurate technical documentation is developed and maintained.

4. Providing engineering direction and oversight to ensure that designs and modifications are consistent with the technical baselines.

\subsubsection{Characterization Project Operations}

LMHC Characterization Project Operations (Operations) operates the Hanford waste tank farms under the management direction of FDH. Operations is responsible for:

1. Reviewing and approving all LDUA Application software changes.

2. Assisting in the identification and establishment of minimum testing criteria to support changes to the LDUA software. 


\subsubsection{Nuclear Safety}

Nuclear Safety is responsible for addressing site safety issues and reviewing and approving all LDUA Application software changes.

\subsubsection{Quality Assurance}

Quality Assurance is responsible for addressing site quality assurance issues and reviewing and approving all LDUA Application software changes.

\subsubsection{Design Agent}

The LDUA Design Agent is responsible for:

1. Implementing any Application-specific software changes to the LDUA Application Software upon turnover to Tank Farm Characterization Project Operations.

2. Maintaining a LDUA software repository for application support under software configuration management.

Based on contract agreements, PNNL is specifically responsible for:

3. Managing a support contract with SPAR Aerospace Ltd., and Sandia National Laboratories (SNL). The agreements provide for SPAR or SNL support on software problems as they arise.

\subsubsection{Software Custodian}

The LHMC Cognizant Engineer/Software Custodian will be responsible for maintaining the Application software and associated configuration files. The LMHC Cognizant Engineer may delegate custodial duties but will be ultimately responsible for proper maintenance of the LDUA Application software and associated configuration files. The LDUA Software Custodian is responsible for the following:

1. Collecting and maintaining the approved LDUA Application Software System Baseline including control of access to the software, distribution to others, control of media, and physical protection of software. 
2. Ensuring that appropriate approvals and reviews are obtained for the LDUA Application Software System Baseline at turn over from PNNL and for any subsequent changes.

3. Assisting in the identification and establishment of minimum testing criteria to support changes to the LDUA software.

4. Providing single point of contact for problem reporting.

5. Providing Engineering support services for LMHC Characterization Project Operations.

6. Developing and maintaining the LDUA software configuration management plan.

\subsubsection{System Administrator}

The System Administrator (Lockheed Martin Services Inc: (LMSI)) is responsible for the following System Software activities:

1. Providing UNIX system administration activities for the LDUA workstations.

2. Ensuring that all operating system upgrades will be performed using LMSI procedures.

\subsubsection{Documentation Control}

LMSI Documentation Control is responsible for the following:

1. Establishing and managing document processing, distribution, record storage, and retrieval.

2. Providing vault storage for documentation. 
TABLE 2.1. Organizational Responsibilities Matrix

\begin{tabular}{|c|c|c|c|c|c|c|c|}
\hline Description & $\begin{array}{l}\text { Design } \\
\text { Authorit } \\
\text { y. }\end{array}$ & $\begin{array}{l}\text { Cognizant } \\
\text { Engineet:Managet }\end{array}$ & $\begin{array}{l}\text { Software } \\
\text { Custodian }\end{array}$ & $\begin{array}{l}\text { Characterization } \\
\text { Operations } \\
.4\end{array}$ & Pesign & Safety & 4 \\
\hline 1. Work Plan & 3,4 & $1,2,3,4$ & 1,2 & $2,3,4$ & 2,3 & 3,4 & 3,4 \\
\hline $\begin{array}{l}\text { 2. Systems Requirement } \\
\text { Specifications }\end{array}$ & $1,2,3,4$ & $2,3,4$ & 1,2 & $2,3,4$ & 2,3 & 3,4 & 3,4 \\
\hline $\begin{array}{l}\text { 3. System Design } \\
\text { Description }\end{array}$ & $1,2,3,4$ & $2,3,4$ & 1,2 & $2,3,4$ & 2,3 & 3,4 & 3,4 \\
\hline 4. Qualification Test Procedure & 3,4 & $1,2,3,4$ & 1,2 & $2,3,4$ & 2,3 & 3,4 & 3,4 \\
\hline 5. Qualification Testing & 3,4 & $1,2,3,4$ & 1,2 & $2,3,4$ & 2,3 & 3,4 & 3,4 \\
\hline 6. Qualification Test Report & 3,4 & $1,2,3,4$ & 1,2 & $2,3,4$ & 2,3 & 3,4 & 3,4 \\
\hline 7. Procedures & 3,4 & $1,2,3,4$ & 2,3 & $2,3,4$ & 2,3 & 3,4 & 3,4 \\
\hline $\begin{array}{l}\text { 8. Software Configuration } \\
\text { Management Plan }\end{array}$ & $1,2,3,4$ & $2,3,4$ & 1,2 & $2,3,4$ & 2,3 & 3,4 & 3,4 \\
\hline 9. Vender Information & 3,4 & $1,2,3,4$ & 1,2 & $2,3,4$ & 2,3 & & \\
\hline 10. Software Release & 3,4 & $1,2,3,4$ & 1,2 & & 2,3 & 3,4 & 3,4 \\
\hline EDT/ECN & 3,4 & $1,2,3,4$ & 1,2 & 3,4 & 2,3 & 3,4 & 3,4 \\
\hline $\begin{array}{l}\text { Software Archive } \\
\text { Listing (SAL) }\end{array}$ & 3,4 & $1,2,3,4$ & 1,2 & 3,4 & 2,3 & & \\
\hline Electronic Media & 3,4 & $1,3,4$ & 1,2 & 3,4 & 2,3 & & \\
\hline
\end{tabular}




\subsection{IMPLEMENTATION}

This software configuration management plan will be implemented immediately upon the release of the Light Duty Utility Arm Computer Software Configuration Management Plan, HNF-2924.

\subsection{POLICIES AND PROCEDURES}

FDH Policies used to implement this plan:

1. HNF-PRO-440, "Engineering Document Change Control Requirements".

2. HNF-PRO-469, "Change Request and Problem Report".

3. HNF-PRO-555, "Software Practices - System Configuration Management Plan".

FDH Procedures used as engineering support documents:

1. HNF-PRO-227, "Engineering Document Identification Requirements".

2. HNF-PRO-239, "Design Analysis Report Requirements".

3. HNF-PRO-241, "Engineering Specification Requirements".

4. HNF-PRO-242, "Engineering Drawing Requirements".

5. HNF-PRO-243, "Interface Control Requirements".

6. HNF-PRO-244, "Engineering Data Transmittal Requirements".

7. HNF-PRO-317, "Engineering Release and Approval Requirements".

8. HNF-PRO-439, "Supporting Document Requirements" (Design Control, Design

Verification, Change Control, Interface Control, Instructions, Procedures, and Drawings).

\subsection{INTERFACE CONTROL}

Programmatic and technical interfaces necessary for the success of the LDUA Software configuration management plan include the appropriate agreements between companies. Agreements between companies will be identified, defined, and controlled per contracts with LMH. Additional organizational or programmatic interfaces are defined in Section 2.2.

\subsection{SOFTWARE CONFIGURATION MANAGEMENT ACTIVITIES}

During the Operations and Maintenance Phase of the LDUA Application software life cycle, problems, errors, difficulties with the software, requests for changes, or requests for new services will be reported to the LHMC cognizant engineer and the designated software custodian. 
The designated Software Custodian will fill out a Software Change Request and Problem Report (SCR/PR) which will be similar in format to the one in HNF-PRO-469 (Each SCR/PR will be numbered and entered into the "Problems" file maintained in the LDUA Application Software file cabinet).

The LHMC Cognizant Engineer will assess the problem or change request and assign it for consideration to the Design Agent. The Design Agent will enter the SCR/PR report into the LDUA Software Custodian notebook.

The Design Agent will determine whether the problems require corrective action, whether corrective action requires changes to the baseline configuration, and how extensive the modifications will be.

If no corrective action is needed, the SCR/PR is closed at that point.

If corrective action is required, based upon the Design Agent determination, LMHC Characterization Engineering grants the authority to modify the affected software components, upgrade the system, or develop new software components to the appropriate individuals (UNIX system problems to LMSI, end effector problems or development to the Design Agent, etc...)

\subsubsection{Software Component upgrades}

For modifications to existing software components, Design Agent will distribute the working copy of the LDUA Application software from their software repository for modification. As PNNL was responsible for delivery of the integrated final system and maintains a support contract with SPAR and SNL it is PNNLs responsibility to coordinate the effort of work among local and off-site organizations.

When modifications to software components are complete and verified, an ECN is approved and issued for the new versions of the software and any revised documents (see Section 6.1). The new version of the software is introduced into the Design Agent's software repository, delivered to the Software Custodian who introduces it into the Application software file cabinet, and the LDUA is re-certified by validation testing. The SCR/PR is closed at this point..

\subsubsection{UNIX System Upgrades}

For modifications to the UNIX system software, LMSI will perform any system administration and operating system upgrade activities. For system administrative activities that have no effect on the Application software, the appropriate documentation must be updated to reflect the system change. For system administrative activities that affect the Application software, modifications to the software components must be completed and verified, an ECN must be approved and issued for the new versions of the software and any revised documents (see Section 6.1). The new version of the software is introduced into the Design Agent's software repository, delivered to the Software Custodian who introduces it into the Application 
software file cabinet, and the LDUA is re-certified by validation testing. The SCR/PR is closed at this point

The LMHC cognizant engineer, the designated Application software custodian manager, and the Design Agent are responsible for ensuring correction of the problem or discrepancy.

\subsubsection{Labeling of Software Media}

Upon successful installation of any LDUA system Application software upgrade, a label will be affixed to the Master copy and system backup with the following information displayed:

1. Name of individual computer system.

2. Drawing number of any logic installed, as appropriate.

3. Revision date for the drawing, as appropriate.

4. Revision number/date for the software.

5. Date installed.

6. Initial of Verifier/Validator.

\subsection{CONFIGURATION IDENTIFICATION}

Application software related documents that are defined in Section 6.1 to be the responsibility of HNF are controlled as Supporting Documents. Other Application software documents are the responsibility of the supplier of the software component, and two copies have been furnished to the Design Agent.

Supporting documents will be issued a supporting document number according to HNFPRO-227, Engineering Document Identification Requirements and released via an Engineering Data Transmittal (EDT) form according to HNF-PRO-244, Engineering Data Transmittal Requirements. Changes to released supporting documents will be controlled via an Engineering Change Notice (ECN) according to HNF-PRO-440, Engineering Document Change Control Requirements.

All Supporting Documents defined in Section 6.1 have been released. During changes to the Application software, the applicable Supporting Documents may be presented in an unreleased form at the review which verifies them but must be released immediately following incorporation of comments from that review. Prior to release, Application software documents will be controlled by the LMHC Cognizant Engineer.

\subsection{CONFIGURATION CONTROL}

Each software file will contain a functional description of the contents of the file. The contents of the file will have the revision history. The revision history will include a description of the initial field release and all subsequent changes to the file. The description will include the following: 
- Revision number/revision date

- Nature of change

- Identity of requester

- Rationale for the change

- Identity of author making the change

\subsection{CONFIGURATION STATUS ACCOUNTING}

The designated Software Custodian will prepare a status accounting file before each field software release. The file will be included in the release software description document. The status accounting will include a list of all software files that make or produce a released product. The status accounting file will include the following:

- Name and revision of the released product

- Name and revision of all software files

- Name of individual computer system where product/software is installed.

Instructions on how to build the software product from the files will include identification of support software. Support software includes compilers, assemblers, editors, operating systems, and other utility software.

\subsection{QUALIFICATION TESTING}

Qualification testing was used for verification and validation of the LDUA Application setup. This was accomplished by comparing the LDUA system performance against the field requirements. The original system baseline (Phase-1) was set upon completion of the LDUA Phase-1 Qualification Test at the end of the development process. The appropriate sections of the Light Duty Utility Arm System Equipment Qualification Test Procedure, WHC-SD-TD-ATP004 were performed to verify that the LDUA field requirements have been met. The Light Duty Utility Arm System Equipment Qualification Test Report, WHC-SD-TD-ATR-004 documented the test results.

\subsection{MEDIA CONTROL}

The form of media used to store approved release software will be 8-mm and 4-mm data cartridges. The software media will be stored in at least two locations. One set of the software media will be stored in a locked fire-resistant file cabinet drawer labeled "software records" in the file named "LDUA Field software." This file cabinet will be located at a location specified by the manager of the Software Custodian. Each approved release software will bear the name "LDUA," the version number, a tape number (sequential integer starting at 1), and the initials of the Verifier/Validator, with the date. The second set of software media is stored in the Design Agent's software repository and is controlled by configuration management. 


\subsection{AUDITS AND REVIEWS}

Acceptance testing will be used to verify that any upgrades to the LDUA Application software are complete. This is accomplished by comparing the LDUA System performance against the field requirements. This method is performed at the time of the LDUA System field Application installation.

\subsection{ACCESS CONTROL}

LDUA System hardware access will be controlled by tank farm access requirements when the system is installed for those portions within the farm boundary and by key access for those portions outside the farm boundary. LDUA Application system software is password-controlled at the Application. The Master tape backup is stored in a locked cabinet. All documentation is controlled by the Hanford Site document control process.

\subsection{BACKUP AND RECOVERY}

LDUA Application system equipment is protected via access control. To ensure redundancy, a second system backup, used for field installations only, is stored with the Master backup in a locked cabinet. It is available with the appropriate tape drives for LDUA Application software re-installation for recovery from damage, loss, or destruction.

\subsection{TOOLS, TECHNIQUES, AND METHODOLOGIES}

None

\subsection{SUPPLIER CONTROL}

The LDUA Application software is maintained in configuration control by the Design Agent in accordance with the project contract. PNNL is responsible for special commercial or contract-developed software from SPAR and SNL. LMHC and the designated software custodian will interface with PNNL for the activities identified in this plan. software:

The following requirements must be met at turnover of any vender produced or modified 1. As-built configuration shall agree with all documentation. 
2. All approved changes shall be incorporated at final turnover.

3. Pertinent vender technical information shall be identified, collected, and entered into the Hanford Site document control system as vender information.

4. Documents shall be written in a format that is compatible with the Hanford Site document control.

\subsection{RECORDS COLLECTION AND RETENTION}

Records handling will be as described in HNF-PRO-564, "Records Retention and Disposal." All LDUA Application software project documentation will be retained through LDUA decommissioning and decontamination (D\&D). Any further record retention requirements will be addressed in the $D \& D$ Plan.

\subsection{LDUA SOFTWARE LIFE CYCLE DOCUMENTS}

The items defined as part of the LDUA Application configuration software and therefore subject to this software configuration management plan are identified as:

LDUA life cycle deliverables as described in the Light Duty Utility Arm Software Development Plan, WHC-SD-TD-SDP-001; as vendor supplied software under contract for Hanford (HNF) as stated in the Quality Assurance Manual, WHC-CM-4-2, QR 19.0; and contract-developed software as specified in the Project Hanford Management Contract (PHMC) software requirements procedure Acquisition and Information Release, HNF-PRO-575.

The Configuration items defined include:

\subsubsection{System Requirement Specifications}

a. Computer Software Requirements Specification for the Light Duty Utility Arm System (CSRS), WHC-SD-TD-CSRS-001.

b. System Requirements Reviews consisted of:

- reviewing the CSRS at the Conceptual Design Review, the Preliminary (25\%) Design Review, and the Detailed (80\%) Design Review

- $\quad$ SNL and SPAR software component reviews as described in the Requirements Verification Report for the Light Duty Utility Arm Baseline System, HNF-2895. 
HNF-2924, Rev.0

\subsubsection{System Design Description}

a. Computer Software Design Description for the Integrated Control and Data Acquisition System Light Duty Utility Arm System (CSDD), HNFSD-TD-CSDD-001.

b. System Design Review consisted of:

- $\quad$ reviewing the CSDD at the Detailed (80\%) Design Review

- $\quad$ SNL and SPAR software component design reviews as described in the Requirements Verification Report for the Light Duty Utility Arm Baseline System, HNF-2895.

\subsubsection{User Documentation}

a. Operations and Maintenance Manual for the LDUA Supervisory Control and Data Acquisition System (LDUA System 4200) and Control Network (LDUA System 4400), HNF-SD-TD-OMM-001.

b. SPAR and SNL User's and Maintenance Manuals, SNL-LDUA-96-006, Rev. 0., SNL-LDUA-96-007, Rev. 0, and SPAR-LDUA-VDD-065 are located in a CVI file at the PNNL LDUA repository. Manual copies are in the Hanford document control system: SPAR manuals via EDT-619886 (May 16, 1997) and SNL manuals via EDT-61885 (May 16, 1997).

\subsubsection{Source Software}

a. Source code software exists for the "World Model" software and the End Effector software supplied by SNL and PNNL.

b. The current LDUA Supervisory Control and Data Acquisition System (LDUA System 4200) and Control Network (LDUA System 4400), Revision 1.0.7. has been continually upgraded and contains all changes made to this date.

c. Source code for the ARM is owned by SPAR and is considered proprietary.

d. The PNNL software repository contains the master copy of all software components including:

SDAS Virtual Instrument Software Code, Version 2/18/97.

SDAS Server Software Code, Version 2/18/97.

SDAS Drivers Software Code, Version 2/18/97.

SCS Position Client Server Software Code, Version 2/18/97.

SCS "World Model" Workcell Software Code, Version 2/19/97.

SCS "World Model" SGCS Software Code, Version 8/16/96.

LDUA Subsystem Controller, LDUA Console Software Code, Version 8/16/96.

Extended Reach End Effector Software Code, Version 8/98. 
6.1.5 Verification and Validation (includes test procedures, test case specifications, and test reports.)

a. Software Test Plan, WHC-SD-SD-TP-006.

b. LDUA Equipment Qualification Test Procedure, WHC-SD-TD-ATP004.

c. LDUA Equipment Qualification Test Report, WHC-SD-TD-ATR-004.

d. Software Implementation Review, letter reports to LDUA Configuration File

e. Software Component Testing were performed by SNL and SPAR and documented in the Integration Test Report - letter report to the LDUA Configuration File. The component test documents are described in Table 5 of the Requirements Verification Report for the Light Duty Utility Arm Baseline System, HNF-2895.

f. Verification and Validation Plan, Light Duty Utility Arm Software Development Plan, WHC-SD-TD-SDP-001, Section 7.0

g. Verification and Validation Report, Requirements Verification Report for the Light-Duty Utility Arm Baseline System, HNF-2895.

h. Verification and Validation Records include all documents listed in this Section 6.1.

I. Verification and Validation Review was covered as a part of the integrated system.

j. Software Configuration Management Plan documents include the PNNL software configuration management plan as stated in the Light Duty Utility Arm Software Development Plan, WHC-SD-TD-SDP-001, Section 9.0 and the Light Duty Utility Arm Computer Software Configuration Management Plan, HNF-2924 (this document). The Software Configuration Management Procedure for PNNL configuration management is described in Section 2.0 "Software Configuration Guidelines" of the LDUA Software Custodian's Notebook, HNF-3223. 


\subsection{SAFETY, RELIABILITY, AND QUALITY ASSURANCE}

\subsection{SAFETY CLASSIFICATION AND SIGNATURE DESIGNATION}

The control systems for the monitoring instruments and systems used for the Hanford waste tank LDUA Characterization system are classified as a non-safety-related General Service system in accordance with the requirements of HNF-PRO-704, "Hazard and Accident Analysis Process." Failure of the LDUA control system does not adversely affect the environment or the health and safety of the personnel operating the system. General design and quality assurance requirements for non-safety items shall be followed.

At a minimum, documentation must satisfy a Q Documentation Approval Designation Level with Safety (S) and Environmental Assurance (E) as deemed appropriate. An ESQ is a designator for documentation that impacts occupational safety (including "as low as reasonably achievable" [ALARA] principles) and environmental monitoring and requires quality assurance verification of conformance to requirements. These have been determined in accordance with HNF-PRO-233, "Review and Approval of Documents."

\subsection{QUALITY ASSURANCE AND QUALITY CONTROL}

All work is conducted in accordance with the relevant quality requirements of HNF-MP599, "Project Hanford Directives: Quality Assurance Program Description.". 


\subsection{REFERENCES}

\subsection{DEPARTMENT OF ENERGY (DOE)}

DOE Order 6430.1A, 1989, General Design Criteria, U.S. Department of Energy, Washington, D.C.

\subsection{FLUOR DANIEL HANFORD, INC}

HINF-2895, Rev. 0, Requirements Verification Report for the Light-Duty Utility Arm Baseline System, Fluor Daniel Hanford, Inc., Richland, Washington.

HNF-3223, Rev. 0, LDUA Software Custodian's Notebook, Fluor Daniel Hanford, Inc., Richland, Washington.

HNF-MP-599, Rev. 1, Project Hanford Directives: Quality Assurance Program Description, Fluor Daniel Hanford, Inc., Richland, Washington.

HNF-PRO-227, Rev. 0, Engineering Document Identification Requirements, Fluor Daniel Hanford, Inc., Richland, Washington.

HNF-PRO-233, Rev. 0, Review and Approval of Documents, Fluor Daniel Hanford, Inc., Richland, Washington.

HINF-PRO-239, Rev. 0, Design Analysis Report Requirements, Fluor Daniel Hanford, Inc., Richland, Washington.

HNF-PRO-241, Rev. 0, Engineering Specification Requirements, Fluor Daniel Hanford, Inc., Richland, Washington.

HNF-PRO-242, Rev. 1, Engineering Drawing Requirements, Fluor Daniel Hanford, Inc., Richland, Washington.

HNF-PRO-243, Rev. 0, Interface Control Requirements, Fluor Daniel Hanford, Inc., Richland, Washington.

HNF-PRO-244, Rev. 0, Engineering Data Transmittal Requirements, Fluor Daniel Hanford, Inc., Richland, Washington.

HNF-PRO-317, Rev. 0, Engineering Release and ApprovalRequirements, Fluor Daniel Hanford, Inc., Richland, Washington. 
HNF-PRO-439, Rev. 0, Supporting Document Requirements, Fluor Daniel Hanford, Inc., Richland, Washington.

HNF-PRO-440, Rev. 1, Engineering Document Change Control Requirements, Fluor Daniel Hanford, Inc., Richland, Washington.

HNF-PRO-469, Rev. 0, Change Requests and Problem Reports, Fluor Daniel Hanford, Inc., Richland, Washington.

HNF-PRO-555, Rev. 0, Software Practices - System Configuration Management Plan, Fluor Daniel Hanford, Inc., Richland, Washington.

HNF-PRO-575, Rev. 0, Acquisition and Information Release, Fluor Daniel Hanford, Inc., Richland, Washington.

HNF-PRO-564, Rev. 0, Records Retention and Disposal, Fluor Daniel Hanford, Inc., Richland, Washington

HNF-PRO-704, Rev. 0, Hazard and Accident Analysis Process, Fluor Daniel Hanford, Inc., Richland, Washington.

HNF-SD-TD-CSDD-001, Rev. 0, Computer Software Design Description for the Integrated Control and Data Acquisition System Light Duty Utility Arm System (CSDD), Fluor Daniel Hanford, Inc., Richland, Washington.

HNF-SD-TD-OMM-001, Rev. 2, Operations and Maintenance Manual for the LDUA Supervisory Control and Data Acquisition System (LDUA System 4200) and Control Network (LDUA System 4400), Fluor Daniel Hanford, Inc., Richland, Washington.

WHC-CM-4-2, QR 19.0, Quality Assurance Mamual, Westinghouse Hanford Co., Richland, Washington.

WHC-SD-TD-ATP-004, Rev. 0, Light Duty Utility Arm Equipment Qualification Test Procedure, Westinghouse Hanford Co., Richland, WA

WHC-SD-TD-ATR-004, Rev. 0, Light Duty Utility Arm Equipment Qualification Test Report, Westinghouse Hanford Co., Richland, WA

WHC-SD-TD-CSRS-001, Rev. 0, Light Duty Utility Arm Software Requirements Specification, Westinghouse Hanford Co., Richland, WA

WHC-SD-TD-SDP-001, Rev 0, Light Duty Utility Arm Software Development Plan, Westinghouse Hanford Co., Richland, WA. 
HNF-2924, Rev.0

WHC-SD-TD-TP-006, Rev 0, Software Test Plan for the Integrated Light Duty Utility Arm

System, Westinghouse Hanford Co., Richland, WA 